\title{
ISOLATION OF TWO GLUCOSIDES OF RHEIN FROM THE LEAVES OF CASSIA ACUTIFOLIA
}

\section{A. S. Romanova and A. I. Ban'kovskii}

Khimiya Prirodnykh Soedinenii, Vol. 2, No. 2, p. 143, 1966

By chromatographing on Kapron a methanolic extract of the leaves of Cassia acutifolia Del. gathered in 1963 in the Southern Kazakhstan Zonal Experimental Station of the All Union Scientific Research Institute for Medicinal and Aromatic Plants, containing $0.85 \%$ of total anthracene derivatives, we have isolated, in addition to glucoaloe emodin, two other anthraglucosides ( $A$ and $B$ ).

Anthraglucoside $\mathrm{A}, \mathrm{C}_{21} \mathrm{H}_{18} \mathrm{O}_{11}, \mathrm{mp} 235^{\circ}-240^{\circ} \mathrm{C}$ (from aqueous acetone) and $252^{\circ}-260^{\circ} \mathrm{C}$ (from aqueous ethanol), gave no depression of the melting point with the glucorhein from rhubarb. Acid hydrolysis of glucoside A gave glucose and an aglycone $\mathrm{C}_{15} \mathrm{H}_{8} \mathrm{O}_{6}, \mathrm{mp} 319^{\circ}-321^{\circ} \mathrm{C}$, which gave no depression of the melting point in admixture with the rhein from rhubarb.

Anthraglucoside $\mathrm{B}, \mathrm{C}_{21} \mathrm{H}_{18} \mathrm{O}_{11}, \mathrm{mp} 183^{\circ}-185^{\circ} \mathrm{C}$ (from aqueous acetone). On acid hydrolysis, glucoside $\mathrm{B}$ gave glucose and an aglycone $\mathrm{C}_{15} \mathrm{H}_{8} \mathrm{O}_{6}$ which also proved to be identical with the rhein from rhubarb.

The IR spectra (mull in paraffin oil) of anthraglucoside A and the glucorhein from Tangut rhubarb were identical, and the spectra of the aglycones of $A$ and $B$ were identical with the spectrum of rhein. The UV spectra of anthraglucosides $A$ and $B$ in aqueous ethanol coincided with the UV spectrum of glucorhein within the limits of error $\left(\lambda_{\text {max }} 227,258\right.$, and $413 \mathrm{~m} \mu)$, and the UV spectra of the aglycones coincided with that of rhein $\left(\lambda_{\max } 230,259\right.$, and $\left.436 \mathrm{~m} \mu\right)$.

It is known [1] that all anthraquinones having two free hydroxyl groups in the $\alpha$ position to the carbonyl group possess an absorption maximum at about 427-432 $\mathrm{m} \mu$. However, if one $\alpha$-hydroxyl group is substituted, this maximum is slifted hypsochromically to $407-413 \mathrm{~m} \mu$. Consequently, in both anthraglucosides the sugar residue is located in the $\alpha$ position.

On paper chromatography in the water-acetone-benzene ( $2: 1: 4$ ) (lower layer) system, the $\mathrm{R}_{f}$ values of anthraglucosides $A$ and $B$ coincided with the $R_{f}$ values of glucorhein and the $R_{f}$ values of their aglycones with the $R_{f}$ values of rhein from rhubarb.

Thus, anthraglucoside $A$ is rhein 8-monoglucoside, identical with the glucorhein that we [2] and Hörhammer, et al., [3] have isolated from Tangut rhubarb, and anthraglucoside B is probably identical with the rhein 1 -monoglucoside of composition $\mathrm{C}_{21} \mathrm{H}_{18} \mathrm{O}_{11} \cdot 0.5 \mathrm{H}_{2} \mathrm{O}$ with mp $170^{\circ} \mathrm{C}$ synthesized by Bellaart [4,5]. The melting points of our glucosides are also close to those of sennosides A and B isolated by Stoll, et al., [6] from the leaves of Cassia augustifolia.

The UV and IR spectra were taken by A. A. Kir'yanov, and the microanalyses of the substances for carbon and hydrogen were performed by E. A. Nikonova and E. A. Plokhova.

\section{REF ERENCES}

1. L. H. Briggs, G. A. Nicholls, and R. M. L. Paterson, J. Chem. Soc. 1718-1722, 1952.

2. A. S. Romanova and A. I. Ban'kovskii, Med. prom. SSSR, no. 10, 18, 1964.

3. H. Wagner, L. Hörhammer, and L. Farkas, Z. Naturf, , 18b, no. 1, 89, 1963.

4. A. C. Bellaart and C. Köningsberger, Recueil Trav. Chim., Rays-Bas., 79, 285, 1960.

5. A. C. Bellaart, Pharmac. Weekbl., 87, 33, 1952.

6. A. Stoll and B. Becker, Fortschritte der Chemie Organischer Naturstoffe, 7, 248, 1950. 